International Journal of Engineering \& Technology, $7(4.34)(2018) 180-183$
International Journal of Engineering \& Technology
SPC
Website: www.sciencepubco.com/index.php/IJET
Research paper

\title{
The Use of Language by the Siamese Community and Its Influences on Cultural Integration: A Case Study in Kampung Keluang, Besut, Terengganu
}

\author{
W. J. Ariffin ${ }^{1 *}$, R. Abdullah ${ }^{1}$, E. M. Rahim² \\ ${ }^{I}$ Faculty of Applied Social Sciences, Universiti Sultan Zainal Abidin, Gong Badak Campus, 21300 Kuala Nerus, Terengganu, Malaysia \\ ${ }^{2}$ Faculty of Educational Studies Universiti Putra Malaysia, 43400 Serdang, Selangor, Malaysia \\ *Corresponding author E-mail: wnjazmina@ unisza.edu.my
}

\begin{abstract}
This study is conducted to observe how language element gives impact to the integration of the Siamese and Malay communities in Kampung Keluang. The study is done by applying two techniques of data collection through fieldwork, namely join observation and thematic interview with the villagers in Kampung Keluang which consist of the Malays and Siamese, besides some other noteworthy individuals. The research findings showed the Siamese community use Malay language as their main language in daily undertakings and their fluency in in using the language has become an element that fosters their integration with the surrounding Malay community. Nevertheless, Siamese language is kept preserved as an identity of the Siamese through informal approach such as the socialization of parents towards their children. Preservation of the Siamese identity through their mother-tongue apparently has not given any repercussion towards integration process of the society in Kampung Keluang. The sharing of language with similar dialect, with the Malay community by the Siamese community proved that they have shared a comparable code system when interacting and it has given positive impact to the social integration in Kampung Keluang.
\end{abstract}

Keywords: Language; Integration; Cultural Sharing; Plural Society; Siamese Community.

\section{Introduction}

Malaysia is a multiracial and multi-ethnic country with diverse cultures respectively. As one of the cultural elements, spoken languages by the society are also varied. Every race, tribe and ethnic must have their own languages and they would preserve these cultural elements against the cultural influence of those much major races. Obviously, language element has continuously been an obstacle in the effort of cross-culture integration.

Basically, culture comprises of two elements which are divided into core element; that is cognitive in terms of its nature and external element; characteristics that is displayed and observable. Therefore, in terms of interracial relation, culture is the strength and the key factor in building the integration and forming the universal harmony. Cultural process is a process that shows how cultures is required, shared and transferred. Hence, this process requires a system called the symbol system. Symbols in culture play a vital role as they form their own meanings. In fact, in order to connect the three cultural elements within a specified society, they have to obtain a shared meaning which allows them to predict and expect what the other members of the society think and do [1]. Being one of the main elements in culture, symbols play an important role since they depend to which extent do the members in the society comprehend those symbols. In this context, symbols are the languages used by each community during interaction. The use of language by someone either to interact or to express something requires a shared comprehension and meaning of the society to allow the messages being conveyed and accepted.

\section{Language Influences Toward Racial Inte- gration}

In [2] pointed out that language is the utmost important tool to form integration among multi-ethnic society. Generally, language is a communication tool used for interaction. Language is seen as a carrier to meanings, symbols or emblems as well as a medium of connection [3]. There are several definitions given to explain the meaning of language. The Sapir-Whorf hypothesis by anthropologists Edward Sapir and Benjamin Whorf in the early 20th century regarding language stated that language has the ability to form how humans think and explore the world. :-

"Human being do not live in the objective world alone, nor alone in the world of social activity as ordinarily understood, but a very much at the mercy of the particular language which has become the medium of expression for their society" [4].

Culture directly forms the language and the language portrays the culture for several societies. Like other cultural elements, language also differs between one society to another and has its own coding system and meanings. Language is also regarded as the main factor for interaction. Interaction between humans consisted of verbal and non-verbal communication. In a society, when interaction occurs between members of a society using the same language, it means that they are sharing the same coding system [5]. The role of language not just only limited to interaction; it goes way beyond communication and portrays the culture of a society. The importance of language is also seen in the continuity process 
of a society in terms of concept, ideas, thought and values held by them [6]. This is due to the fact that language enables human beings to create an intellectual and moral system through several mediums such as arts and literature and it is inheritable from one generation to a new generation.

In the context of Siamese and Malay community in this research, the use of Malay language in communication needs to be expanded to mould the national identity of Malaysian citizenship paralle with the Federal Constitution that upholds Malay language as the national language. The position of Malay language is further strengthen with the National Language Act 1967 that shows the government is committed in ensuring that Malay language is upheld and thus becomes the unity language used by the whole citizens. This statement is supported by [7] who pointed out that the government enforcement in terms of the national language is precise as the role of language is important and it becomes a tool to unite the multi-ethnic and multiracial societies with diverse cultures, faiths, religions and backgrounds.

\section{Materials and method}

\subsection{Siamese Community in Kampung Keluang, Besut}

Generally, the Siamese community refers to a group of people who declare themselves as of Siamese descendant and also approved by other ethnicities taking into consideration the behavioural and characteristics that is considered pertinent to the Siamese race which include the linguistics aspect, ethnical identity, historical values and tradition [8]. In other words, one must admit oneself as Siamese and practice the characteristics of Siamese culture and also being accepted and approved by other ethnics. The features of Siamese culture refer to its religion which is Buddhism, the language, place of worship which is the temple, and other elements belong to the Siamese cultural properties [8].

The Siamese community in Terengganu is not as many as those in the state of Kelantan where many of them mainly reside in the districts of Tumpat, Pasir Mas and Bachok. Terengganu is one of the states with high percentage of Malays. 94.2 percent out of a million Terengganuites consists of the Malays; followed by 2.5 percent Chinese, 0.3 percent Indians and 3.0 percent represent the other races [9]. The Siamese community falls under the category of other races and indeed a minority in this state.

Besut is a district in Terengganu which populates Siamese residents who live in a village named Kampung Keluang. This village is surrounded by other villages where majority of the residents are Malays. Kampung Keluang is a settlement which is situated in a rural area, located in the province of Kampung Raja and administrated by the Village Safety and Development Committee (JKKK) Kampung Keluang. The total number of residents in Kampung Keluang is 1592 people consisting of the Malays with 1325 people (83\%), 45 Chinese (3.5\%), 214 Siamese $(13.5 \%)$, and only 8 Indians $(0.5 \%)$. Kampung Keluang has a majority of Malays and Siamese is the second highest of race in this village. Having said that however, in terms of amount, the Siamese are far less than Malays with a ratio 1:6. This has made them a minority who lives in a residential area monopolized by Malays.

The Siamese community has long built a settlement here with the Chinese and Malays. They have been residing and building a societal living with other races for such a long period of time. The pattern of their social life has partly seems to fuse well with local culture they are living in.

\subsection{Method}

This research adopts the ethnographic approach that associates with the way of life of the community and requires the researchers to elaborate on the lifestyle and culture of humans naturally [10] In an ethnographic study, field work is the main medium for researchers in order to obtain primary data based on certain resources. During this data gathering process, researchers have stayed together with the sample group, involved with their daily activities and established a strong relationship with them. This phase requires the researchers to secure a strong relationship with the sample group because it influences the findings.

Throughout the research process, researchers have involved with the tasks and activities of the villagers for over 12 months and continued to do so until they obtained enough data to be analysed. During this period, the observation technique followed a series of interviews with the respondents both formally and informally. Through this technique, researchers have entailed the community activities together with the villagers to observe the elements of integration among the Siamese and Malay community. Interviews were conducted through three phases which are formal, informal and focus group discussion (FGD). Researchers have conducted formal interviews with a row of leaders from the Siamese and Malay community as well as several villagers that pose significance to the research needs. Formal interviews were conducted to acquire official information and specific views from the respondents regarding a subject matter. However, researchers were keen on conducting interviews informally especially when doing activities with villagers in order to obtain much authentic findings in terms of data validity. Interviews through conversations with the villagers either individually or in groups were adhered to themes specified and provided that they were within the context of the research. Primary data obtained from the field work were analysed manually. Apart from that, researchers also opted for secondary data and sorted them using N-Vivo software to support the research findings.

\section{Results and discussion}

There are two main languages being used by the Siamese in Kampung Pak Kiang namely the Malay language and their mother language which is Siamese language. The Siamese language used in this village is different from the Siamese language used by the Siamese community in Thailand and even different from the Siamese community living in the northern side of the Malaysian Peninsula. From interviews that have been conducted it is found that the language used by the Siamese here in more traditional and different in terms of dialect which is the use of words and style of pronunciation.

The Malay language is the main language medium used in daily matters and also the medium of communication between Siamese community and the Malay community. The Malay language being spoken by the Siamese here followed the verbal slang of the Kelantanese Malays. Kelantan dialect is indeed synonym with the Malay community living in Besut. Similarly, the Siamese people in Besut who are very fluent in Malay language and conversing in slang like the Kelantanese Malays. However, within the Siamese community, the main language they use at home and to speak among them is the Siamese language. For them, this is the only way to preserve the use of Siamese language among their family members especially in the younger generations.

Following the interview with Mr Siri Neng Buah who is originated from Kampung Pak Kiang, he stated that Siamese language used by the Siamese community in Besut is slightly different from the Siamese language used by the Siamese community in the Northern Peninsula such as in Perlis and Kedah in terms of the use of words and sentence arrangement. He further stated that the Siamese language used by the Siamese community in Besut is more classical and often use old words.

"Siamese people here, in Pak Kiang, use the ancient Siamese language in the dialect which is no longer being used now by the modern community of today. For example, the word 'naplau' which means trousers. Only we use the word now. Our language is only similar to the Siamese in Kampung Semerak (Pasir Puteh Kelantan) and partly in Kampung Balai (Bachok Kelantan). Our style is also simple that it has brought to another word phrase which sounds differently". 
Siamese language is used only within the Siamese particularly between members of the family and among the Siamese residents themselves. The use of Siamese language is rather limited since it could not be used to interact with the Malays thus making them to become fluent in using Malay language.

Malay language is the second major language been used. The Malay language which has special position in the history of civilization of the Malay society is also used by other societies of the same root. As Malay is the main language, the Siamese people are assimilated by the use of the language and consider it as their own cultural language alongside their mother language that has never been forgotten and still well preserved. The usage of Malay language in their daily matters shows a sharing of same language system with the Malays has happened. They used Malay language when talking to the Malay people whether they are the Malays from the village or outside. A lot of conversations that took place at restaurants, groceries, markets, or even in the street use Malay language since their daily activities involve meeting a lot of the Malay people. Aside from that, not only official events like Siamese and the State Representatives' assembly and Charity Giving Ceremony for the Siamese community, festival celebration held by the Siamese community like the Loy Krathong Celebration and Songkran Festival also use Malay language as the main language. A shared language system is the key features to successfully form interactions between two parties. When two parties interact, both parties actually have prepared to accept the same cultural patterns and even the same coding system [5]. Though it may seem simple, sharing the Malay language of the same dialect with the Malay language by the Siamese community proves that they are sharing the same coding system when they interact. The desire of the Siamese community to use Malay language for communication shows that the sharing of cultural elements occurs with excellence.

For the Siamese community, the two aspects - language and traditional customs - are preserved and inherited to the younger generations. The aspect of language possesses its own function in the culture of a society. Language plays the role as a marker, recorder and interpreter of the intercultural and intra-cultural aspects of a society that owns the language [11]. As one of the key elements in the cultural components, language not only stands as a symbolic system used to for communication, but its roles goes way beyond the angle of identity. Language provides identity to its speakers since the language contains concepts, ideas and values inherited by its society $[12,13]$. The Siamese community preserves their mother tongue by using the Siamese language at home with their family members. For example, parents use Siamese language to communicate with their children. This approach is a way of cultural socialization in the aspect of language to the younger generations.

Even though the use of Siamese language is only limited among the Siamese community, they are still able to maintain the use of Siamese language, especially among the teenagers and youths who would later become the heir to the Siamese cultural tradition. The Siamese community here are exposed to two cultures - Malay cultures and Chinese cultures. Thus, there are three spoken languages used in this village; Malay language, Siamese language and Chinese language. There is uniqueness for the Siamese families that have family members of Chinese descendants because the amalgamation features are shown in the language used. They mastered Siamese language, Chinese language and Malay language since their daily activities revolves around the Malay society.

However, the findings are slightly different if compared to the ability of the Siamese community in Siamese written language. The researchers found out that there are children that are illiterate in reading and writing the Siamese characters.

"We speak using Siamese language at home. Talking to the children using Siamese language, so that they are fluent in Siamese language. Moreover, where else would we use this Siamese language, only at home... the youths nowadays do not know much on writing Siamese characters. Like the Malays, most of them are not proficient in Jawi characters. The same goes to these Siamese, there are those who cannot write and read Siamese characters."

Nevertheless, the researchers learned that there is a significant difference in terms of the practice of their mother language that stays among the Siamese community, but it does not hinder the sustainability of the communities' integration in this village. In this context, there are two branches which can be seen as contrary that is since it possesses both features of assimilation and pluralism. The assimilation process in language occurs when the Siamese community uses the Malay language in their daily activities which shows that they have practiced one of the cultural components of the Malays in the aspect of language. They mastered Malay language and comprehended the pragmatic values according to the mould of the locals. Yet, on one side, they do not abandon their traditional language, use it in suitable times and try to ensure that their traditional language continues to be used by the younger generations.

\section{Conclusion}

Pluralism in mother language context where the sustaining of Siamese as the language of tradition among the community in Kampung Keluang has never hinder the bond between the Siamese people and the Malays to maintain a harmonious environment. The process of sustaining the language identity has not divided these communities in their interaction with the Malays in the surrounding as they themselves are well versed in Malay language and using it in most of their daily matters.

The uniqueness in the lifestyle of Siamese community within the Malays in Kampung Pak Kiang shows a few examples of cultural process such as acculturation, assimilation, accommodation, and also social pluralism. These processes are in line with the nature of the culture itself that is so dynamic hence enabling the society to adapt with the current necessities. What is obvious is that the Siamese community in here has long been integrating with the Malays in their own ways. There are assimilated cultural elements, acculturating experience, and seemingly there are also elements which remain in contrast with the culture of the dominant community. These changing and adapting cultural processes has given a big influence in the stabilization of racial relationship between the Malay community and the Siamese community after so long

\section{Acknowledgement}

This research that has been conducted in Kampung Keluang would have not been realized without the support and cooperation from the residents who were always ready and willing to share thoughts. They never hesitated to share and give inputs and knowledge for the purpose of fulfilling the requirements for this study. Many thanks to all the Siamese descendants and the Malays residing in Kampung Keluang. Appreciation is also forwarded to Mr Alias Abd Ghani, Mr Eryin, Mr Awa Or, Ms Husna, and the late Siri Neng Buah, as well as some other individuals for assisting in this language study between the Siamese and the Malays. The authors would like to thank the Research Management, Innovation and Commercialization Centre, Universiti Sultan Zainal Abidin, Terengganu, Malaysia for providing the financial assistance to support the publication fee of this article.

\section{References}

[1] Ferraro, G., \& Susan, A. (2010). Cultural anthropology an applied perspective. Wadsworth Cengage Learning.

[2] Zahari, A. R. (2003). Ke arah perpaduan nasional: Ciri-ciri dan perlaksanaannya. In S. A. Baharuddin et al. (Eds.), Membina Bangsa Malaysia Jilid 1 Perpaduan Negara. Selangor: Universiti Kebangsaan Malaysia Press.

[3] Abdul, R., \& Amat, J. M. (2011). Sosiolinguistik dan Bahasa Melayu. Universiti Kebangsaan Malaysia. 
[4] Lustig, M. W., \& Koester, J. (1993). Intercultural competence interpersonal communication across cultures. Hyper Collins College Publishers.

[5] Sarbaugh, L. E. (1995). Komunikasi antara budaya. Dewan Bahasa dan Pustaka.

[6] Robins, R. H. (1992). Linguistik umum sebuah pengantar. Kanisius Press.

[7] Wan Norhasniah, W. H. (2012). Peradaban dan perkauman di Malaysia: Hubungan etnik Melayu-Cina. Universiti Malaya Press.

[8] Yusoff, I. (1993). Psikologi permainan dan sukan. In A. H. Othman (Ed.), Psikologi Melayu. Kuala Lumpur: Dewan Bahasa dan Pustaka, pp. 295-343.

[9] Unit Perancangan Ekonomi Negeri Terengganu. (2010). Data asa 2010 Terengganu. Percetakan Yayasan Islam Terengganu Sdn Bhd.

[10] Mcneill, P. (1990). Research method. Routledge.

[11] Cesar, A. H. (1987). Towards a model for the study, development and use of national languages in multilingual societies. In A. Omar (Eds.), National Language and Communication in Multilingual Societies. Kuala Lumpur: Dewan Bahasa dan Pustaka.

[12] Abdullah, H. (2000). Bahasa, pemikiran dan survival bangsa Melayu. In D. Harahap \& A. J. Anuar (Eds.), Kumpulan Kertas Kerja Kolokium Bahasa Pemikiran Melayu dan Indonesia. Kuala Lumpur: Dewan Bahasa dan Pustaka, pp. 60-83.

[13] Jessica, O. H. L., Wan, N., \& Ridhuan, T. A. (2014). Bahasa Melayu dalam pendidikan merentas perpaduan kaum. In K. M. Said (Ed.), Perpaduan Nasional Dalam Pelbagai Perspektif. Terengganu: Universiti Sultan Zainal Abidin Press and Majlis Profesor Negara. 